\title{
ASSESSMENT OF GENETIC VARIATION IN WILD MYRTLE (MYRTUS COMMUNIS L.) GENOTYPES GROWING AROUND THE MEDITERRANEAN REGION OF TURKEY
}

\author{
TÜZÜN-KIS, B. - İKTEN, H. ${ }^{*}$ \\ Department of Agricultural Biotechnology, Faculty of Agriculture, Akdeniz University, Antalya, \\ Turkey \\ *Corresponding author \\ e-mail: haticeikten@akdeniz.edu.tr \\ (Received 28 $8^{\text {th }}$ Sep 2021; accepted 22 ${ }^{\text {nd }}$ Dec 2021)
}

\begin{abstract}
Myrtle (Myrtus communis) grows naturally on the Mediterranean coast and the Aegean region of Turkey and is used as medicine, food and ornamental plant. Availability of genetic resources with genetic diversity constitutes an important material for researching genes that may be needed in future breeding studies. The goal of this study was to analyze the genetic diversity of the myrtle genotypes in order to develop further cultivation, regeneration or breeding strategies. Nine traits (length, width, weight and color of the fruit, number of seeds, weight of seeds, pulp weight, length, and width of the leaf) were evaluated. PCR amplification was performed using Simple Sequence Repeats (SSR) and Inter- Primer Binding (iPBS) primers. The variation was found between genotypes in terms of the morphological characters considered. Using molecular analyses, the genetic diversity among the genotypes was determined based on the 64 SSR and 80 polymorphic iPBS bands. The genetic variation obtained by morphological and molecular analyses shows that these genotypes may be useful for future breeding and cultivation practices and can be considered as valuable genetic resources. It has also been shown that some of the iPBS primers were highly polymorphic and can be used in phylogenetic analyzes and mapping studies of myrtle.
\end{abstract}

Keywords: genetic relationship, genetic resources, iPBS, SSR, diversity

\section{Introduction}

Myrtle (Myrtus communis L.) is a diploid $(2 \mathrm{n}=2 \mathrm{x}=22)$, medicinal and aromatic plant and grows wildly on the rocky slopes, Pinus brutia forests and coastal regions of the Mediterranean Basin (Özkan and Güray, 2009). These plants can reach up to $5 \mathrm{~m}$ in height and grow at altitudes ranging from 50-500 $\mathrm{m}$ above sea level. It is an evergreen shrub with ovate lanceolate leaves, white flowers and is very aromatic because of the high oil content of its leaves (Agrimonti et al., 2006). The fruits have two different color (Fig. 1), a dark blue and a white (yellowish-white) form (Traveset et al., 2001; Messaoud et al., 2011; Serçe et al., 2010). Dark blue fruits contain higher polyphenolic content and antioxidant activity than white fruits and they are rich in $\alpha$-pinene, linalool and $\alpha$-terpineol whereas white fruits were rich in myrtenyl acetate and unsaturated fatty acids like linoleic and oleic acids (Messaoud et al., 2011) and myrtle pigmented berries are a good anthocyanin source. The myrtle has value as ornamental and aromatic plant and shows hypoglycemic, antimicrobial, antihemorrhagic properties (Özek et al., 2000; Sepici et al., 2004). The aromatic leaves contain essential oil which are used in the pharmaceutical, cosmetic, food industries (Mulas, et al., 1998; Messaoud et al., 2005) and for liquor production. Nineteen compounds, concerning mostly to polyphenol compounds and a new class of hydrolysable tannins were identified in these berries (mostly in seeds) for the first time by D'Urso et al. (2017). Composition of essential oils found quite variable with a number of compounds ranging from 31 to 78 depending on 
cultivar (Usai et al., 2020). There is an increasing interest to myrtle for medicinal uses and food industries. The increasing demand is causing uncontrolled collection of leaves and berries from the wild plants. To protect the genetic resources and control of reduction of myrtle populations, a domestication program and a conservation program was carried out starting in 1995 in Sardinia island (Mulas and Cani, 1999) and evaluation of the selected genotypes and breeding programs within the scope of this program continues (Medda and Mulas, 2021). The same scenario is also true for Turkey. Uncontrolled harvesting of leaves, and fruits, cutting branches for ornamental usage, decoration at traditional wedding ceremonies (Özkan and Güray, 2009) and increased construction activity cause the reduction of diversity of genotypes. Genetic diversity is a major benchmark in the choice of genetic resources and wild genotypes are important particularly for tolerance to biotic and abiotic stresses. Well-characterized genetic resources play an important role in guiding breeding studies, since breeders are usually looking for plant material containing desirable agricultural traits (e.g. disease resistance, or fruit traits). Management of genetic resources by morphological and molecular characterization, evaluation and conservation is necessary to maximize the benefits of genetic resources. Analysis of genetic diversity in germplasm collections can provide reliable classification of genotypes and help to understand the capacity of the gene pool for specific breeding purposes. Therefore, morphological, and molecular characterization of germplasm is an essential tool and ideally molecular characterization should be carried out by a suitable a marker system that is polymorphic and can reveal genetic variations. A limited number of studies have been conducted on morphological characterization of myrtle (Ciccarelli et al., 2008; Serçe et al., 2010; Messaoud and Boussaid, 2011).
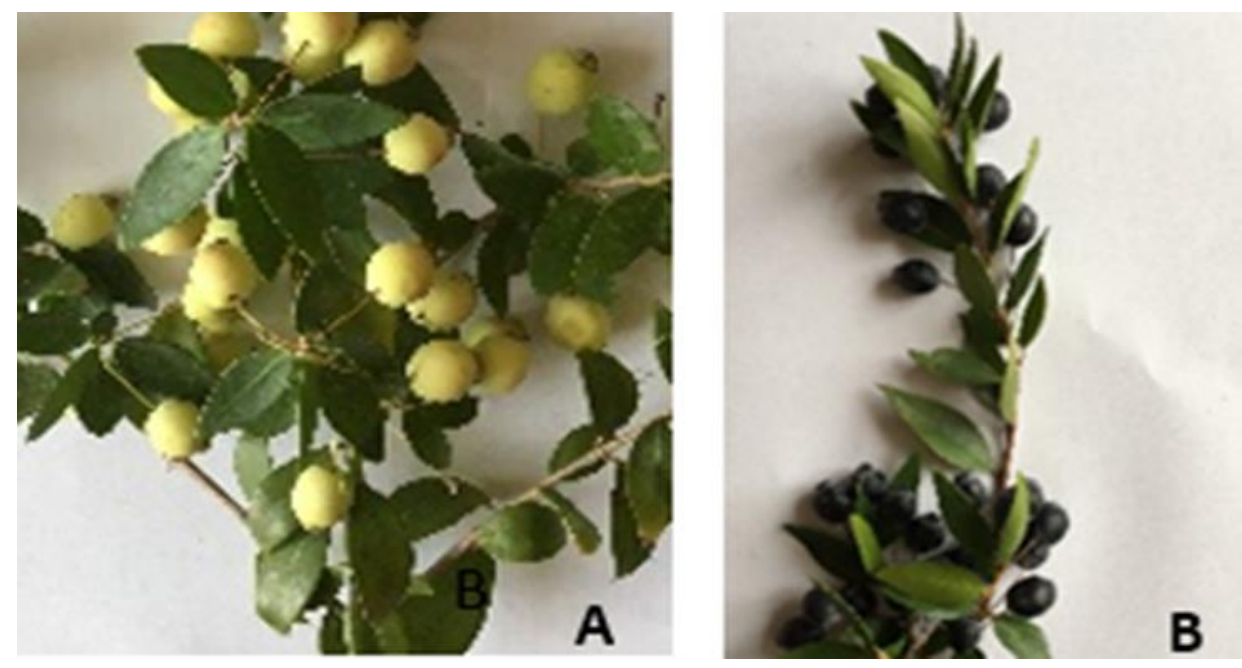

Figure 1. Myrtus communis samples collected from: (A) Mersin, Erdemli-Kumkuyu, white fruited morphs, (B) Muğla, Marmaris-Armutalan, dark blue fruited morphs

Studies at the molecular level for the identification, characterization and relatedness analysis of Myrtus communis (myrtle; Myrtaceae) have been performed using molecular markers, such as AFLP (Bruna et al., 2005; Agrimonti et al., 2006; Bruna et al., 2007; Albaladejo et al., 2009; Melito et al., 2014, 2016, 2017; Messaoud et al., 2011), RAPD (Messaoud et al., 2007), ISSR (Melito et al., 2013; Simsek et al., 2019), SRAP 
(Ghafouri and Rahimmalek, 2018) and SSR (Albaladejo et al., 2010; Nora et al., 2014; Corona et al., 2017; Mele et al., 2019).

The goal of this study was to analyse the genetic diversity of the naturally grown myrtle genotypes around the Mediterranean Region of Turkey based on morphological and molecular characterization in order to develop further cultivation, regeneration or breeding strategies. Molecular characterization was performed by using iPBS Kalendar et al. (2010) and previously described SSR primers by Albaladejo et al. (2010).

SSR markers have some advantages over other marker systems that include high potential for automation, co-dominant inheritance, distribution throughout the genome, high levels of polymorphism and repeatability. Small amount of DNA is sufficient for amplification of SSR markers (Park et al., 2009) and have been successfully used to examine genetic diversity, fingerprinting and genotyping in different plant species (Abdurakhmonov, 2016).

The inter-primer binding site (iPBS) amplification technique utilizes the conserved parts of - primer binding site (PBS) sequences that are universally found almost all long terminal repeats (LTR) retrotransposon and used for determining the variations caused by retrotransposon movements or recombinations (Kalendar and Schulman, 2014). The LTR transposon elements contain a conserved region for binding of tRNA that act as a primer in the conversion of the retrotransposon RNA to DNA before enters its new position in the genome. iPBS markers (Kalendar et al., 2010; Kalendar and Schulman, 2014) have been used to investigate the genetic relationship among the genotypes of apricot (Prunus armeniaca L.) (Baránek et al., 2012) and apple (Malus pumila Mill.) (Kuras et al., 2013), guava (Psidium guajava L.) (Mehmood et al., 2015), grapevine (Vitis vinifera L. ssp. sativa D.C.) (Milovanov et al., 2019), Laurel (Laurus nobilis L.) (Karik et al., 2019), wild Cicer species (Andeden et al., 2013), pea (Pisum sativum) (Baloch, 2015), Motherwort (Leonurus cardiaca L.) (Borna et al., 2016). To our knowledge, no prior studies have examined iPBS markers in Myrtus communis.

Genetically diverse germplasm resources constitute an important material for researching genotypes that may carry the desired characters. Identification and protection of Myrtus communis genotypes which are widely grown naturally in the Mediterranean and Aegean coasts of Turkey, are important in terms of providing material for future breeding studies and preserving genetic diversity.

\section{Material and methods}

\section{Plant material}

The 48 myrtle genotypes were used as study material (Table 1). The leaves and fruit samples were collected from 20 different locations (included 8 provinces) covering an area of $\sim 1200 \mathrm{~km}$ along the Mediterranean coastline and Aegean region of Turkey in the period of fruit ripening (October to January) in 2017 and 2018 from either very ancient myrtle trees or young shrubs (Fig. 2). The map in Figure 3 and Table 1 shows the sampling locations.

\section{Morphological analysis}

On each genotype nine morphological traits (length, width, weight and color of the fruit, number of seeds, weight of seeds, pulp weight, length and width of the leaf) were evaluated. The samples were examined morphologically using the method described by 
Melito et al. (2016) and Uzun et al. (2016). The fruits were harvested and measured in full ripening stage and a sample of 50 fruits and leaves was taken from each genotype from all sides of the shrubs. The leaves were stored at $-70{ }^{\circ} \mathrm{C}$ for further molecular analysis. All analyses of morphological characteristic were performed using analysis of variance (ANOVA) in SPSS 20.0 software package (IBM, 2020). Normality test performed, and the data showed normal distribution. Variance analysis (one-way ANOVA-Duncan) was used to determine variations among the genotypes based on measured properties. Pearson's correlation analysis was performed to find correlation between the morphological characteristics and altitude.
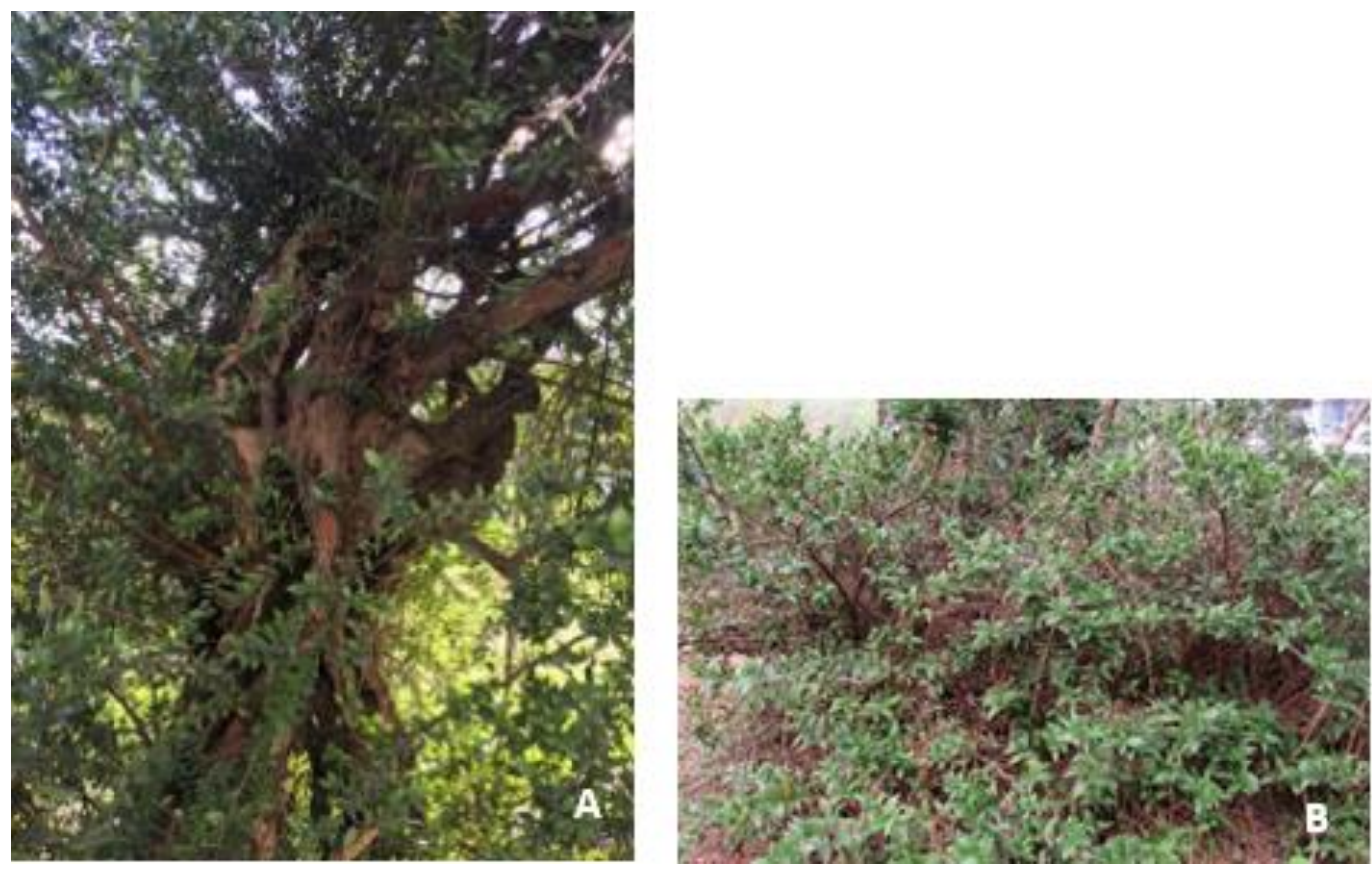

Figure 2. (a) The 'Old myrtle' shrub (Antalya, Bahtıli), (b) myrtle shrub (Antalya-Göynük)

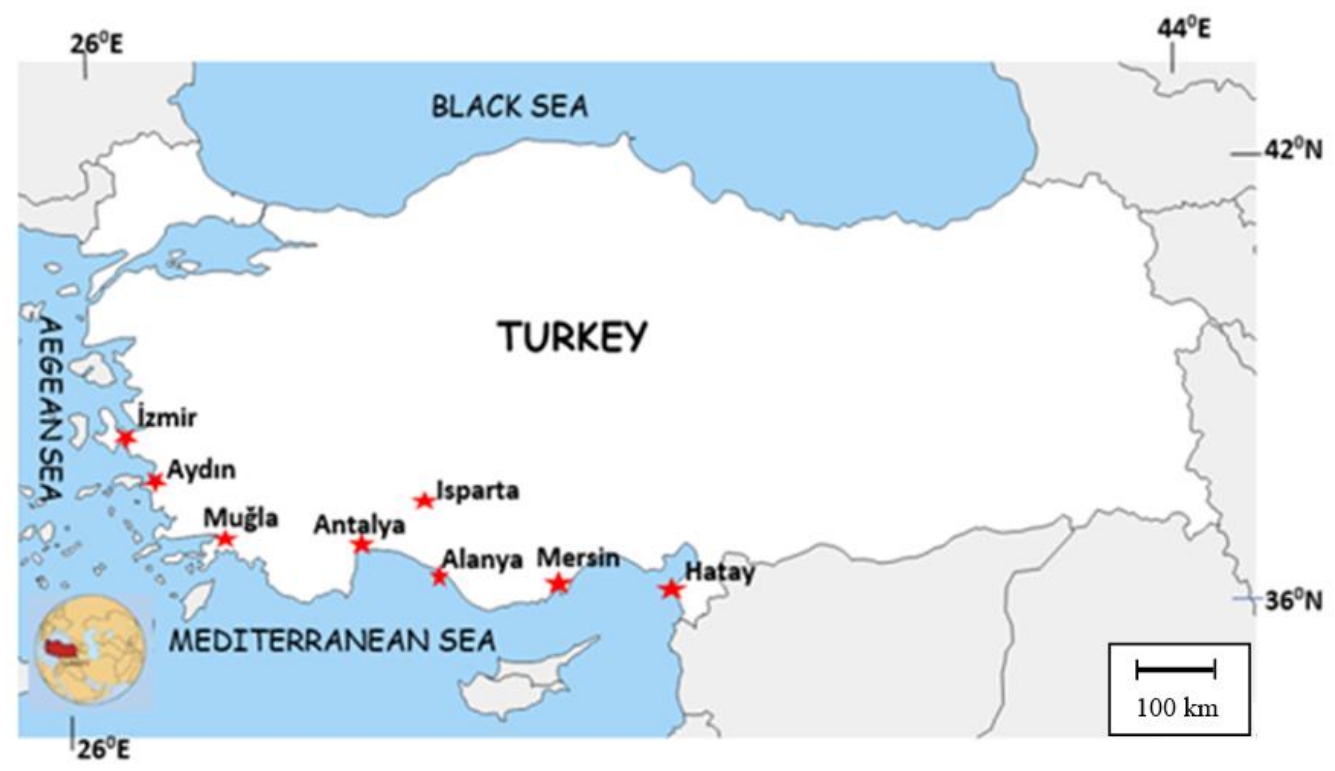

Figure 3. The sampling areas in the Mediterranean Region of Turkey 
Table 1. List of the studied genotypes, their identification codes, fruit color, location, geographical coordinates of the collection sites

\begin{tabular}{|c|c|c|c|c|c|}
\hline $\begin{array}{l}\text { Genotype } \\
\text { code }\end{array}$ & Fruit color & $\begin{array}{c}\text { Introduced genotype } \\
\text { location }\end{array}$ & Longitude & Latitude & $\begin{array}{l}\text { Altitude } \\
(\mathbf{m})\end{array}$ \\
\hline Hty1B & Dark blue & Hatay, Samandağı, Fidanlı & E3601'28.54”' & $\mathrm{N} 36^{\circ} 09^{\prime} 04.75^{\prime \prime}$ & 141 \\
\hline Ant3B & Dark blue & Antalya, Kumluca, Belen & E30²3’34.80” & N3622’28.66”' & 505 \\
\hline Ant $4 \mathrm{~W}$ & White & Antalya, Kumluca, Belen & $\mathrm{E} 30^{\circ} 23^{\prime} 34.80^{\prime \prime}$ & $\mathrm{N} 36^{\circ} 22^{\prime} 28.66^{\prime \prime}$ & 505 \\
\hline Ant5W & White & Antalya, Kumluca, Belen & $\mathrm{E} 30^{\circ} 23^{\prime} 34.80^{\prime \prime}$ & $\mathrm{N} 36^{\circ} 22^{\prime} 28.66^{\prime \prime}$ & 505 \\
\hline Ant6W & White & Antalya, Kumluca, Belen & $\mathrm{E} 30^{\circ} 23^{\prime} 34.80^{\prime \prime}$ & $\mathrm{N} 36^{\circ} 22^{\prime} 28.66^{\prime \prime}$ & 505 \\
\hline Ant7B & Dark blue & Antalya, Alanya, Okurcalar & E31०41'51.00" & $\mathrm{N} 36^{\circ} 39^{\prime} 00.00^{\prime \prime}$ & 23 \\
\hline Ant8W & White & Antalya, Alanya, Okurcalar & E314'51.00”, & $\mathrm{N} 36^{\circ} 39^{\prime} 00.00^{\prime \prime}$ & 23 \\
\hline Ant9B & Dark blue & Antalya, Göynük Kanyon & E30॰32’02.75” & $\mathrm{N} 36^{\circ} 40^{\prime} 57.40^{\prime \prime}$ & 64 \\
\hline Ant10B & Dark blue & Antalya Göynük Kanyon & E30³2’02.75” & $\mathrm{N} 36^{\circ} 40^{\prime} 57.40^{\prime \prime}$ & 64 \\
\hline Ant11W & White & Antalya, Kemer, Arslanbucak & E30॰33'35.14” & $\mathrm{N} 36^{\circ} 36^{\prime} 10.05^{\prime \prime}$ & 122 \\
\hline Ant12W & White & Antalya, Kemer, Kuzdere & E30³1'53.71” & $\mathrm{N} 36^{\circ} 34^{\prime} 59.51^{\prime \prime}$ & 45 \\
\hline Ant13W & White & Antalya, Kemer, Kuzdere & E30³1'53.71” & $\mathrm{N} 36^{\circ} 34^{\prime} 59.51^{\prime \prime}$ & 45 \\
\hline Ant14B & Dark blue & Antalya, Kemer, Çamyuva & E30³4’00.00" & $\mathrm{N} 36^{\circ} 34^{\prime} 00.00^{\prime \prime}$ & 9 \\
\hline Ant15B & Dark blue & Antalya, Kemer, Çamyuva & $\mathrm{E} 30^{\circ} 34^{\prime} 00.00^{\prime \prime}$ & $\mathrm{N} 36^{\circ} 34^{\prime} 00.00^{\prime \prime}$ & 9 \\
\hline Ant16B & Dark blue & Antalya, Kemer, Tekirova & $\mathrm{E} 30^{\circ} 31^{\prime} 35.01^{\prime \prime}$ & N36 $30^{\prime} 06.93^{\prime \prime}$ & 14 \\
\hline Ant17W & White & Antalya, Kemer, Tekirova & $\mathrm{E} 30^{\circ} 31^{\prime} 35.01 ”$ & $\mathrm{~N} 36^{\circ} 30^{\prime} 06.93^{\prime \prime}$ & 14 \\
\hline Isp18W & White & Isparta, Çobanpınar & E3048'24.23” & $\mathrm{N} 37^{\circ} 23^{\prime} 03.06^{\prime \prime}$ & 339 \\
\hline Ant19B & Dark blue & Antalya, Alanya, Dereköy & $\mathrm{E} 32^{\circ} 02^{\prime} 01.54 ”$ & N36³9’31.24"' & 659 \\
\hline Ant20W & White & Antalya, Manavgat, Hatipler & E312ㄴ'38.94” & $\mathrm{N} 36^{\circ} 48^{\prime} 40.10^{\prime \prime}$ & 42 \\
\hline Ant21W & White & Antalya, Finike, Sahilkent & $\mathrm{E} 30^{\circ} 12^{\prime} 17.06^{\prime \prime}$ & $\mathrm{N} 36^{\circ} 20^{\prime} 15.72^{\prime \prime}$ & 21 \\
\hline Ant22B & Dark blue & Antalya, Akdeniz Univ. & E30॰39’07.97’' & N36 $533^{\prime} 31.48^{\prime \prime}$ & 27 \\
\hline Ant23B & Dark blue & Antalya, Akdeniz Univ. & E30³9’07.97’' & $\mathrm{N} 36^{\circ} 53^{\prime} 31.48^{\prime \prime}$ & 27 \\
\hline Izm24W & White & İzmir, Değirmen Dere & $\mathrm{E} 27^{\circ} 08^{\prime} 58.03^{\prime \prime}$ & $\mathrm{N} 27^{\circ} 37^{\prime} 37.83^{\prime \prime}$ & 20 \\
\hline $\operatorname{Izm} 25 \mathrm{~B}$ & Dark blue & İzmir, Değirmen Dere & $\mathrm{E} 27^{\circ} 08^{\prime} 58.03^{\prime \prime}$ & $\mathrm{N} 27^{\circ} 37^{\prime} 37.83^{\prime \prime}$ & 20 \\
\hline Izm26W & White & İzmir, Değirmen Dere & $\mathrm{E} 27^{\circ} 08^{\prime} 58.03^{\prime \prime}$ & $\mathrm{N} 27^{\circ} 37^{\prime} 37.83^{\prime \prime}$ & 20 \\
\hline $\mathrm{Mgl} 27 \mathrm{~W}$ & White & Muğla, Datça & $\mathrm{E} 27^{\circ} 41^{\prime} 09.04^{\prime \prime}$ & $\mathrm{N} 36^{\circ} 43^{\prime} 34.38^{\prime \prime}$ & 10 \\
\hline Mg128B & Dark blue & Muğla, Datça & $\mathrm{E} 27^{\circ} 41^{\prime} 09.04^{\prime \prime}$ & $\mathrm{N} 36^{\circ} 43^{\prime} 34.38^{\prime \prime}$ & 10 \\
\hline Mg129W & White & Muğla, Marmaris, Armutalan & E28 $144^{\prime} 15.13^{\prime \prime}$ & N36 $51 ' 23.64^{\prime \prime}$ & 37 \\
\hline Mgl30B & Dark blue & Muğla, Marmaris, Armutalan & E28 $8^{\circ} 14^{\prime} 15.13^{\prime \prime}$ & N36 $51 ' 23.64 "$ & 37 \\
\hline Izm31B & Dark blue & İzmir, Menemen, Yamanlar & $\mathrm{E} 27^{\circ} 13 ’ 38.47^{\prime \prime}$ & $\mathrm{N} 38^{\circ} 32^{\prime} 44.90^{\prime \prime}$ & 946 \\
\hline Ayd32B & Dark blue & Aydın & E28०29'11.03" & $\mathrm{N} 37^{\circ} 48^{\prime} 42.13^{\prime \prime}$ & 1358 \\
\hline Ant33B & Dark blue & Antalya, Baht11 & E30³4’27.71” & $\mathrm{N} 36^{\circ} 53^{\prime} 16.82^{\prime \prime}$ & 38 \\
\hline Ant34W & White & Antalya, Serik, Şatırlı & $\mathrm{E} 30^{\circ} 34^{\prime} 27.71^{\prime \prime}$ & $\mathrm{N} 36^{\circ} 53^{\prime} 16.82^{\prime \prime}$ & 15 \\
\hline Ant35W & White & Antalya, Konyaaltı & E3042'47.96" & $\mathrm{N} 36^{\circ} 53^{\prime} 48.81^{\prime \prime}$ & 56 \\
\hline Ant36W & White & Antalya, Geyikbayırı & $\mathrm{E} 30^{\circ} 27^{\prime} 53.86^{\prime \prime}$ & $\mathrm{N} 36^{\circ} 52^{\prime} 31.58^{\prime \prime}$ & 614 \\
\hline Ant37B & Dark blue & Antalya, Gökçam & $\mathrm{E} 30^{\circ} 32^{\prime} 46.99^{\prime \prime}$ & $\mathrm{N} 36^{\circ} 53^{\prime} 41.11^{\prime \prime}$ & 66 \\
\hline Ant38B & Dark blue & Antalya, Gökçam & E30॰32’46.99” & $\mathrm{N} 36^{\circ} 53^{\prime} 41.11^{\prime \prime}$ & 66 \\
\hline Ant44B & Dark blue & Antalya, Gökçam & E30॰32’46.99”' & $\mathrm{N} 36^{\circ} 53^{\prime} 41.11^{\prime \prime}$ & 66 \\
\hline Mrs48W & White & Mersin, Erdemli, Kumkuyu & $\mathrm{E} 34^{\circ} 12^{\prime} 00.00^{\prime \prime}$ & $\mathrm{N} 36^{\circ} 32^{\prime} 00.00^{\prime \prime}$ & 183 \\
\hline Mrs49W & White & Mersin, Erdemli, Kumkuyu & $\mathrm{E} 34^{\circ} 12^{\prime} 00.00^{\prime \prime}$ & $\mathrm{N} 36^{\circ} 32^{\prime} 00.00^{\prime \prime}$ & 183 \\
\hline Mrs50B & Dark blue & Mersin, Erdemli, Ayaş & $\mathrm{E} 34^{\circ} 11^{\prime} 00.00^{\prime \prime}$ & $\mathrm{N} 36^{\circ} 29^{\prime} 00.00^{\prime \prime}$ & 0 \\
\hline Ant51B & Dark blue & Antalya, Döşemealtı & $\mathrm{E} 30^{\circ} 36^{\prime} 04.35^{\prime \prime}$ & $\mathrm{N} 37^{\circ} 01^{\prime} 22.89^{\prime \prime}$ & 302 \\
\hline Ant52B & Dark blue & Antalya, Döşemealtı & E30³6’04.35" & $\mathrm{N} 37^{\circ} 01^{\prime} 22.89^{\prime \prime}$ & 302 \\
\hline Ant53W & White & Antalya, Döşemealtı & E30³6’04.35" & $\mathrm{N} 36^{\circ} 55^{\prime} 16.06^{\prime \prime}$ & 302 \\
\hline Hty55B & Dark blue & Hatay, Erzin, Kuzuyuk & $\mathrm{E} 36^{\circ} 16^{\prime} 12.10^{\prime \prime}$ & $\mathrm{N} 37^{\circ} 01^{\prime} 22.89^{\prime \prime}$ & 469 \\
\hline Hty56W & White & Hatay, Erzin, Kuzuyuk & $\mathrm{E} 36^{\circ} 16^{\prime} 12.10^{\prime \prime}$ & $\mathrm{N} 36^{\circ} 55^{\prime} 16.06^{\prime \prime}$ & 469 \\
\hline Ant57B & Dark blue & Antalya, Alanya, Okurcalar & E3141'51.00” & N36³9’00.00"' & 23 \\
\hline Mgl59W & White & Muğla, Fethiye & $\mathrm{E} 29^{\circ} 07^{\prime} 34.85^{\prime \prime}$ & N36³9'33.29"' & 25 \\
\hline
\end{tabular}

\section{Molecular analysis}

\section{DNA extraction}

Genomic DNA was extracted from leaf tissues of 48 genotypes using a modified cetyltrimethylammonium bromide (CTAB) method (Doyle and Doyle, 1990). The leaves $(200 \mathrm{mg})$ were cut into small pieces with a help of scalpel and grind to a fine 
paste in a $600 \mu \mathrm{l}$ CTAB buffer $(2 \%$ CTAB, EDTA $20 \mathrm{mM}$, Tris-Cl $100 \mathrm{mM}, \mathrm{NaCl}$ $1.4 \mathrm{M}, 0.2 \%$ Mercaptoethanol) using mortar and pestle. The CTAB/plant extract mixture transferred to the Eppendorf tube and incubated $1 \mathrm{~h}$ at $65{ }^{\circ} \mathrm{C}$. After two times Chloroform: Isoamyl alcohol (24:1) treatment and 15 min centrifugation was performed at $13,000 \times \mathrm{g}$, then upper aqueous phase was transferred to clean tube and $500 \mu \mathrm{l}$ isopropanol alcohol added. Following the centrifugation for $15 \mathrm{~min}$, the upper phase was discarded. The pellet was washed with $70 \%$ ethanol two times and leave to dry (approximately $15 \mathrm{~min}$ ) at the room temperature. The quality of DNA was checked by $1 \%$ agarose gel electrophoresis with ethidium bromide staining.

\section{DNA amplification with SSR}

PCR amplification was performed using 12 SSR primer pairs developed by Albaladejo et al. (2010) (Table 4). PCR reactions were performed in a 15- $\mu$ l volume containing 20-30 ng genomic DNA, $0.2 \mathrm{mM}$ dNTPs, $1.5 \mathrm{mM} \mathrm{MgCl} 2,0.5 \mu \mathrm{M}$ each primer, and $1 \mathrm{U}$ Taq DNA polymerase (Thermo). An adaptor sequences (GGAAACAGCTATGACCAT) were ligated to at its 5' end of the reverse primers and fluorescently labeled with either IRDye 700 or IRDye 800 fluorescent dyes according to the protocol by Schuelke (2000).

Amplifications were conducted using a program with an initial denaturation step at $95^{\circ} \mathrm{C}$ for $3 \mathrm{~min}$. followed by 35 cycles at $94{ }^{\circ} \mathrm{C}$ for $45 \mathrm{~s}, 50-65^{\circ} \mathrm{C}$ for $30 \mathrm{~s}$ and $72{ }^{\circ} \mathrm{C}$ forl min with a final cycle of $72{ }^{\circ} \mathrm{C}$ for $5 \mathrm{~min}$. A 1.5- to $2-\mu$ l aliquot of PCR product (depending on the performance of amplification of each primer pair) was mixed with $10 \mu \mathrm{l}$ of loading dye including $98 \%$ formamide, $10 \mathrm{mM}$ EDTA, $0.25 \%$ bromophenol blue, $0.25 \%$ xylenecyanol and denatured at $95{ }^{\circ} \mathrm{C}$ for $4 \mathrm{~min}$. and placed in ice until loaded. PCR products were separated on a $25 \mathrm{~cm} 6 \%$ polyacrylamide gel (0.25 mm thick) containing acrylamide: bis-acrylamide (19:1), $8 \mathrm{M}$ urea, and TBE 1X using a 32-well square comb. The separated bands were visualized in a Li-Cor -IR2 4200 Genetic Analyzer (Li-Cor Biosciences).

\section{DNA amplification with iPBS}

Twelve iPBS primers were selected from the study of Kalender et al. (2010) (Table 5). DNA amplification was carried out by using a modified protocol of Kalendar et al. (2010). PCR was performed in a volume of $15 \mu \mathrm{L}$ containing $10 \mathrm{mM}$ Tris- $\mathrm{HCl}(\mathrm{pH}$ 9.0), $50 \mathrm{mM} \mathrm{KCl}, 1.5 \mathrm{mM} \mathrm{MgCl} 2,0.2 \mathrm{mM}$ of each dNTP, 10 pmol of each primer, 50 ng genomic DNA, and $1 \mathrm{U}$ Taq DNA polymerase (Thermo) using the following temperature profile: $95{ }^{\circ} \mathrm{C}$ for $3 \mathrm{~min}, 35$ cycles of denaturation at $94{ }^{\circ} \mathrm{C}$ for $30 \mathrm{~s}$, annealing at $50-60{ }^{\circ} \mathrm{C}$ (the annealing temperature varied depending on the primer used) for $45 \mathrm{~s}$ and $72{ }^{\circ} \mathrm{C}$ for $1 \mathrm{~min}$, and an extension step at $72{ }^{\circ} \mathrm{C}$ for $5 \mathrm{~min}$. PCR was performed two times for some primers to confirm band pattern consistency. Products were separated by gel electrophoresis in $2 \%(\mathrm{w} / \mathrm{v})$ agarose gels and visualized by staining ethidium bromide under UV light.

\section{Data analysis}

The allelic data matrix of "1" or " 0 " was used to calculate the genetic analysis by using NTSYS (Numeracal Taxonomy Multivariate Analysis System, NTSYS-pc version 2.1 Exeter Software, Setauket, N.Y. USA (Rohlf, 1993). A genetic similarity matrix was constructed with in the SIMGEND module and similarity matrices were utilized to 
construct the UPGMA (unweighted pair group method with arithmetic average) dendrograms. Principal component analysis (PCA) was performed to show the differences among the genotypes. Eigen values were calculated using the EIGEN module and based on the variance-covariance matrix. Two dimensional plots calculated between each two pairs of the 48 myrtle genotypes. The polymorphism information content (PIC) of SSR and iPBS markers was calculated as the mean of the PIC of each allele using the formula of Roldan-Ruiz et al. (2000) (Eq. 1).

$$
\mathrm{PICi}=2 \mathrm{fi}(1-\mathrm{fi})
$$

where "PICi" is the polymorphism information content of allele "I" and "fi" is the frequency of occurrence of allele "I" (fragment present) in the 48 individuals.

\section{Results and discussion}

\section{Morphological analysis}

Morphological characterization of genetic resources provides the most important guiding information for identification, classification, and conservation of the genetic resources. Knowledge of morphological characters is the first step in the parental selection in the breeding programs. In this study the important morphological traits of the myrtle genotypes were determined in their natural ecosystems. Fifty fruits and leaves from each genotype were evaluated in terms of morphological characters and results are shown in Table 2.

The fruit weight, fruit length and fruit width ranged 0.05 to $1.18,6.44 \mathrm{~mm}$ to $15.69 \mathrm{~mm}$ and 4.16 to $12.72 \mathrm{~mm}$ respectively. Results showed that the highest values for six out of the eight morphological characters (fruit weight, length, width, number of seed per fruit, seed weight, pulp weight) were recorded in genotype Ant8W. The lowest value for fruit weight, width, seed weight and pulp weight were measured in genotype Ant17W (Table 2). In the previous studies Melito et al. (2016) reported the fruit weight from $0.25 \mathrm{~g}$ to $0.34 \mathrm{~g}$, fruit length $7.18 \mathrm{~mm}$ to $9.03 \mathrm{~mm}$ and fruit width 5.74 to 8.22 in Sicily. Uzun et al. (2016) measured highest values for fruit weight $1.33 \mathrm{~g}$, fruit length $15.33 \mathrm{~mm}$ and fruit width $13.27 \mathrm{~mm}$ in the myrtle genotypes with white fruit color in coastal conditions of Antalya, Turkey. The highest and lowest values for fruit weight, length and width were recorded as 0.26 to $2.01,7.52$ to $16.73 \mathrm{~mm}$ and 5.52 to $14.74 \mathrm{~mm}$ respectively by Yildirım et al. (2013) in the study carried out in Adana and Mersin province of Turkey. In the current study the number of seed for per fruit, seed weight and pulp weight are ranged 2.2-22.4, 0.02-0.21 g and $0.03-0.93 \mathrm{~g}$ respectively. Melito et al. (2016) reported a narrower range than we find between the highest and lowest values of the seed number for per fruit (10.34-18.43), seed weight $(0.04 \mathrm{~g}-0.05 \mathrm{~g})$ and pulp weight $(0.20 \mathrm{~g}-0.29 \mathrm{~g})$. In the present work the seed weight ranged $0.02-0.21$ in genotypes with white berries and 0.02-0.13 in genotypes with black berries. The number of seeds ranged 2.2- 22.4 in genotypes with white berries and $2.2-10.8$ in genotypes with black berries. Measurements varied between 13.95 (Ant22) and $32.85 \mathrm{~mm}$ (Ant13W) for leaf length, 5.5 (Ant23B) and $15.3 \mathrm{~mm}$ (Ant35W) for leaf width. The studied genotypes showed variation for all morphological traits evaluated. There were statistically significant differences ( $\mathrm{p}<0.01$ ) among the genotypes for all fruit and leaf traits measured (Table 3). Samples were collected from different altitudes from 0 to $1358 \mathrm{~m}$. According to the 
results of the correlation analysis, there were negative and significant $(\mathrm{p}<0.01)$ correlations between altitude and fruit length $\left(\mathrm{r}=-, 088^{* *}\right)$, fruit weight $\left(\mathrm{r}=-, 078^{* *}\right)$ and pulp weight $(-, 082 * *)$. Medda et al. (2021) found no effect of altitude on leaf total phenols, whereas a negative correlation was reported on berries total phenols and tannins concentrations.

Table 2. Means of fruit and leaf characteristics for wild myrtle genotypes (mean $\pm S E$ )

\begin{tabular}{|c|c|c|c|c|c|c|c|c|}
\hline $\begin{array}{c}\text { Genotype } \\
\text { code }\end{array}$ & $\begin{array}{l}\text { ruit length } \\
\text { (mm) }\end{array}$ & \begin{tabular}{|c|}
$\begin{array}{c}\text { Fruit width } \\
(\mathrm{mm})\end{array}$ \\
\end{tabular} & $\begin{array}{c}\begin{array}{c}\text { Fruit } \\
\text { weight }(\mathrm{g})\end{array} \\
\end{array}$ & \begin{tabular}{|c|} 
Number of \\
seed per fruit
\end{tabular} & \begin{tabular}{|c|}
$\begin{array}{c}\text { Seed weight } \\
(\mathrm{g})\end{array}$ \\
\end{tabular} & $\begin{array}{c}\text { Pulp weight } \\
\text { (g) }\end{array}$ & \begin{tabular}{|c|}
$\begin{array}{c}\text { Leaf length } \\
(\mathrm{mm})\end{array}$ \\
\end{tabular} & \begin{tabular}{|c|}
$\begin{array}{c}\text { Leaf width } \\
(\mathrm{mm})\end{array}$ \\
\end{tabular} \\
\hline Hty1B & $8.55 \pm 0.16$ & $6.81 \pm 0.17$ & $0.19 \pm 0.01$ & $6.06 \pm 0.43$ & $.06 \pm 0.00$ & $0.12 \pm 0.009$ & $23.40 \pm 0.64$ & $9.59 \pm 0.38$ \\
\hline Ant3B & & \pm 0.09 & $19 \pm 0.00$ & \pm 0.22 & 00 & $14 \pm 0.004$ & $.44 \pm 0.83$ & $16 \pm 0.34$ \\
\hline Ant $4 \mathrm{~W}$ & $.8 \pm 0.16$ & $10.89 \pm 0.13$ & $83 \pm 0.02$ & $19.87 \pm 1.18$ & 01 & & $32.06 \pm 1.25$ & 0.57 \\
\hline & & & & & & & & \\
\hline Ant6W & $3 \pm 0.13$ & $0 \pm 0.11$ & $32 \pm 0.01$ & $6.75 \pm$ & $09 \pm 0.00$ & $0.23 \pm 0.008$ & $19.79 \pm 0.80$ & $9.37 \pm 0.29$ \\
\hline Ant7B & $56 \pm 0.14$ & 0.12 & $55 \pm 0.02$ & & $09 \pm 0.00$ & $0.45 \pm 0.01$ & $24.35 \pm 0.73$ & $9.51 \pm 0.26$ \\
\hline Ant8W & $9 \pm 0.26$ & $12.72 \pm 0.20$ & \pm 0.04 & 19 & 01 & & \pm 1.04 & \pm 0.40 \\
\hline & & & $0.20 \pm$ & & & 006 & & \\
\hline Ant10B & & & & & & & & \\
\hline Ant11W & & 10.1 & & $11.08 \pm$ & & & & \\
\hline Ant12W & & \pm 0.11 & & & & 05 & $4 \pm 0.98$ & $11.37 \pm$ \\
\hline Ant13W & & & & & & & & \\
\hline & & & & & & & & \\
\hline & & & & & & & & \\
\hline & & & & & & & & \\
\hline & \pm 0.11 & $16 \pm 0.11$ & $0.05 \pm 0.00$ & $2.66 \pm 0.26$ & $02 \pm$ & 0.03 & & \\
\hline & $22 \pm 0.26$ & $10.75 \pm$ & & & & & & \\
\hline & & & & & & & & \\
\hline Ant & & & & & & & & \\
\hline & & $10.10=$ & & $8.86 \pm 0.50$ & $0.10 \pm$ & 02 & & 10.95 \\
\hline Ant & & & & & & & & \\
\hline Ant23B & $9+0.12$ & $99 \pm 0.06$ & $.18 \pm 0.00$ & $5.44 \pm 0.31$ & $07 \pm 0.00$ & $11 \pm 0.004$ & & \\
\hline & & & & & & & & \\
\hline & & & & & & & & \\
\hline $\mathrm{W}$ & & & & & & & & 11.01 \\
\hline & & & 01 & & & & & \\
\hline & 07 & 15 & 01 & 77 & 00 & 09 & 20 & 6.7 \\
\hline & & & & & & & & \\
\hline & & & & & & & & \\
\hline Izr & & 4 & 00 & & 00 & 0.1 & 60 & 8.0 \\
\hline Ayd32B & $10.71 \pm 0.18$ & $8.16 \pm 0.15$ & & & & & & 11.2 \\
\hline Ant33B & $9.5 \pm 0.26$ & $6.26 \pm 0.14$ & $0.20 \pm 0.01$ & 4.8 & $0.05 \pm 0.00$ & \pm 0.01 & $26.24 \pm 0.35$ & 10.5 \\
\hline & & & & & & & & \\
\hline An & & & & & 0.1 & & 32 & 15. \\
\hline Ant36W & 22 & 16 & 02 & & 0.0 & 02 & 0.6 & 11.2 \\
\hline Ant37B & $7.59 \pm 0.19$ & $5.72 \pm 0.14$ & $0.13 \pm 0.00$ & $2.26 \pm 0.21$ & $0.03 \pm 0.002$ & $0.10 \pm 0.007$ & $27.45 \pm 0.65$ & $11.77 \pm 0.30$ \\
\hline Ant38B & & $4.77 \pm 0.15$ & $0.09 \pm 0.00$ & $2.22 \pm 0.13$ & $0.02 \pm 0.001$ & $0.06 \pm 0.007$ & $24.04 \pm 0.69$ & $9.08 \pm 0.33$ \\
\hline & & & & & & & & \\
\hline Mrs48W & 16 & 12 & 22 & 15 & 0 . & 02 & 1.09 & 0.42 \\
\hline Mrs49W & \pm 0.16 & $8.31 \pm 0.18$ & $5 \pm 0.02$ & $2.26 \pm 0.14$ & $0.03 \pm 0.003$ & $0.32 \pm 0.02$ & $20.79 \pm 0.71$ & $7.45 \pm 0.27$ \\
\hline Mrs50B & $11.73 \pm 0.16$ & $6.90 \pm 0.10$ & $0.22 \pm 0.00$ & $6.58 \pm 0.55$ & $0.07 \pm 0.005$ & $0.14 \pm 0.005$ & $23.41 \pm 0.84$ & $9.29 \pm 0.28$ \\
\hline & & & & & & & & \\
\hline & & & & & & & & \\
\hline Ant53W & $8.18 \pm 0.22$ & $6.72 \pm 0.25$ & $0.19 \pm 0.01$ & 34 & $0.10 \pm$ & $0.09 \pm 0.01$ & $22.15 \pm 0.62$ & $9.71 \pm 0.31$ \\
\hline Hty55B & $9.53 \pm 0.12$ & $7.34 \pm 0.11$ & $0.24 \pm 0.00$ & $8.14 \pm 0.40$ & $0.09 \pm 0.003$ & $0.14 \pm 0.008$ & $22.29 \pm 0.53$ & $9.90 \pm 0.27$ \\
\hline Hty56W & $11.41 \pm 0.29$ & $8.52 \pm 0.28$ & $0.43 \pm 0.03$ & $9.13 \pm 0.90$ & $0.10 \pm 0.01$ & $0.33 \pm 0.02$ & $28.84 \pm 0.77$ & $13.71 \pm 0.31$ \\
\hline & & & & & & & $32.06 \pm 1.19$ & $7.87 \pm 0.34$ \\
\hline Mg159W & $13.41 \pm 0.45$ & $11.22 \pm 0.39$ & $0.81 \pm 0.06$ & $14.45 \pm 2.04$ & $0.12 \pm 0.01$ & $0.69 \pm 0.05$ & $27.39 \pm 0.77$ & $13.38 \pm 0.41$ \\
\hline
\end{tabular}

*Sufficient number of fruits could not be collected for Ant15B, Ant16B and Ant22B 
Tüzün-Kis - İkten: Assessment of genetic variation in wild myrtle (Myrtus communis L.) genotypes growing around the Mediterrranean Region of Turkey -863 -

Table 3. ANOVA of morphological characteristics

\begin{tabular}{c|c|c|c|c|c}
\hline & Sum of squares & df & Mean square & F & Sig. \\
\hline Fruit length & 7269.623 & 44 & 165.219 & 137.175 & .000 \\
Fruit weight & 84.074 & 44 & 1.911 & 147.834 & .000 \\
Number of Seed & 28091.839 & 44 & 638.451 & 44.178 & .000 \\
Seed weight & 2.932 & 44 &, 067 & 47.557 & .000 \\
Pulp weight & 59.594 & 44 & 1.354 & 152.736 & .000 \\
Leaf length & 39853.370 & 47 & 847.944 & 25.153 & .000 \\
Leaf width & 46946.082 & 47 & 998.853 & 1.562 & .009 \\
\hline
\end{tabular}

The mean differences are significant 0.01 level

\section{Molecular analysis}

Molecular analysis was done separately with two marker system as well as in combination of SSR and iPBS data sets.

\section{Simple sequence repeats (SSR)}

Eleven out of the 12 markers designed for Myrtus communis (Albaladejo et al., 2010) were polymorphic in 48 wild myrtle genotypes and produced a total of 64 alleles. The number of fragments varied from one to nine with an average 5.3 per SSR primer pair (Table 4). In line with previous studies of Corona et al. (2017) and Mele et al. (2019) five SSR primer pairs, namely Myrcom2, Myrcom4, Myrcom7, Myrcom8, Myrcom11, were highly polymorphic, each producing 7-9 alleles. Three primers Myrcom5, Myrcom6, Myrcom9 were moderately polymorphic, each producing 4 to 5 alleles. The remaining four SSR primer pairs, Myrcom1, Myrcom3, Myrcom10, Myrcom12, were less polymorphic by producing two to three alleles each (Table 3). The findings for Myrcom1 and Myrcom12 primers of current study are in accordance with findings of Corona et al. (2017) with 2 alleles for each primer and a similar band pattern was obtained by Albaladejo et al. (2010) for the Myrcom1, Myrcom5, Myrcom7 primer pairs. The PIC values of SSR primers ranged from 0.45 (Myrcom1, Myrcom6) to 0.99 (Myrcom8) with an average of 0.70 (Table 4). Similarity index ranged from 0.31 to 1.00 based on the similarity matrix (data not shown). A phylogenetic tree obtained based on the similarity matrix for SSR markers shown in Figure 4. The genetic distance coefficients ranged from 0.63 to 0.97 with an average of 0.82 . Based on phylogenetic analysis, the 48 genotypes were clearly clustered into two major clades (A and B) at the 0.63 similarity coefficient level. Clades A divided two groups (A1 and A2) at the similarity index of 0.65. Seven different genotypes collected from Antalya province are clustered together in cluster A1. Similar pattern was observed in accession from İzmir and Aydin (both located on the Aegan region) that grouped together in cluster A.2. The cluster A2. 1 contained 18 accessions 13 of which have white fruit color. Seven genotypes clustered in A2.1. clade namely Ant4W, Ant8W, Ant11W, Ant20W, Ant34W, Mrs48W, Hty56W found genetically similar by SSR markers. B1.2.2 included 13 genotypes with both black and white berries and collected from different regions.

\section{Inter-primer binding site ( $i P B S$ )}

Initially 30 primers were screened with bulk DNA, which was prepared by taking equal amounts of DNA samples from each genotype and 12 polymorphic primers were 
selected for further investigations (Table 5). The iPBS analysis was performed on 48 genotypes revealing 135 total and 80 polymorphic bands with a mean of 11.25 total bands for each tested primer. Maximum 14 fragments were generated with primers 2378 and 2394, minimum 8 fragments were generated with 2078 and 2221. A total of 80 polymorphic bands were obtained with a mean of 6.66 bands for each primer and 2378 was the most polymorphic one with 13 bands, while primer 2221 produced only two polymorphic bands. The sizes of reproducible and scorable bands ranged from 175 bp to $2000 \mathrm{bp}$. Percentage of polymorphism ranged from $25.0 \%$ (2221) to $92.8 \%$ (2378), with an average polymorphism of $57.26 \%$ across all the genotypes. Similarity index ranged from 0.44 to 1.00 based on the similarity matrix (data not shown). The PIC observed for 2078 marker was the highest thus, this marker could be more efficient in genotypic differentiation of myrtle genotypes. A dendrogram based on UPGMA analysis with iPBS data is shown in Figure 5. The 47 genotypes were grouped into one cluster (B) at the 0.58 similarity coefficient level whereas one genotype (Ant19) separated from the population (A) showing less similarity coefficient (0.58) with other genotypes studied. Genotypes within clade B are further grouped into two subclusters, B1 and B2 at the 0.63 similarity coefficient level. Clade B2 comprised 4 genotypes and clade B1 comprised 43 genotypes and separated into two sub-group. Six genotypes with white fruit color, collected from different geographical locations namely: Ant $4 \mathrm{~W}$, Ant $21 \mathrm{~W}$, Ant35W, Mrs48W, Hty56W, Mgl59W found genetically similar and located in the subcluster B1.1. The genotypes Ant11W, Isp18W, Ant20W, Ant34W placed in the cluster B1.1 also found genetically similar with iPBS markers (Fig. 5). Ant4W, Mrs48W, Hty56W and Ant11W, Ant20W genotypes were found genetically similar by both SSR and iPBS markers.

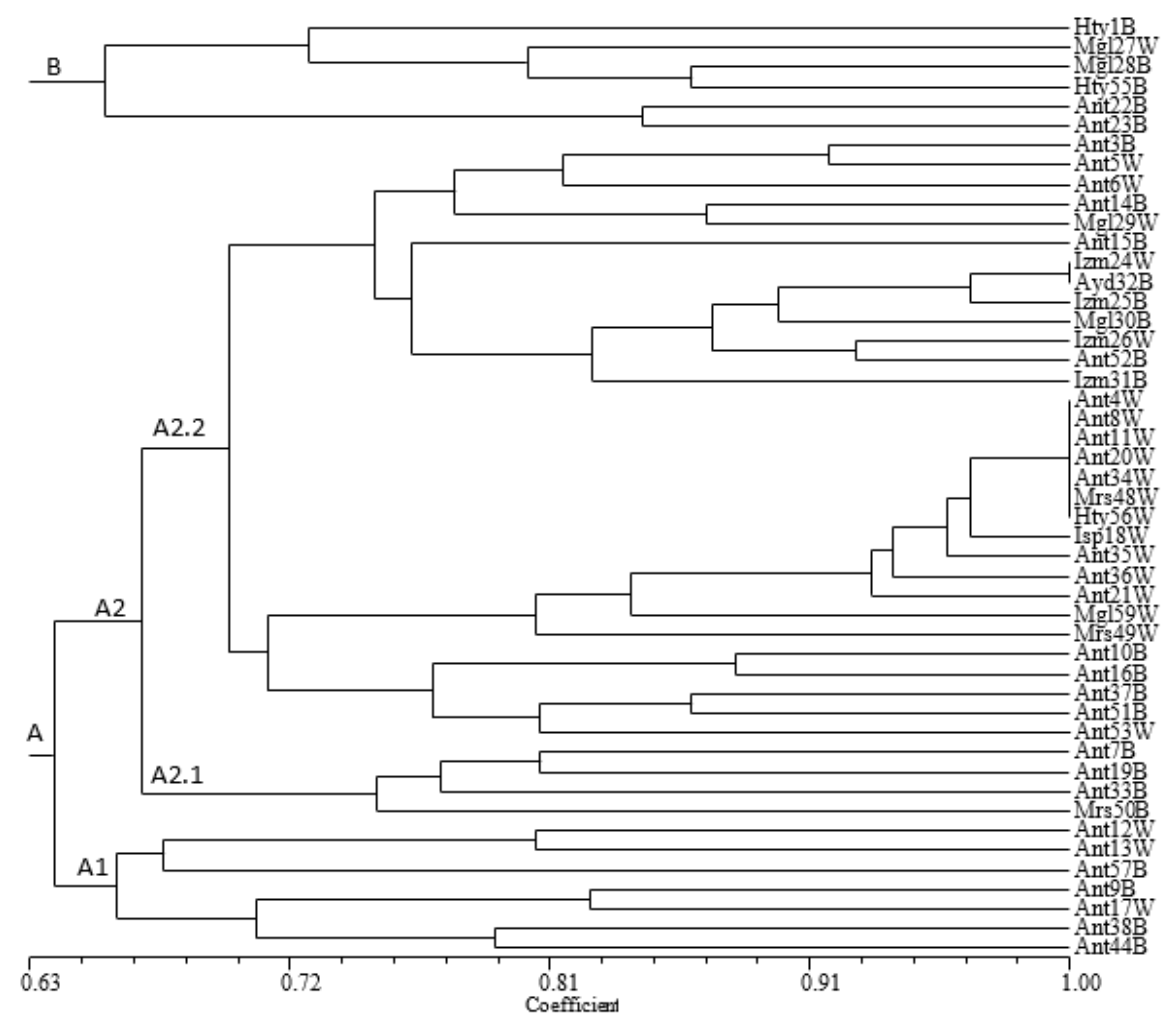

Figure 4. Dendrogram for 48 Myrtus communis accessions derived from a UPGMA cluster analysis based on 12 SSR markers 
Table 4. List of SSR primers and sequence, number of bands and polymorphic bans, allele size range ( $b p$ ) and polymorphic information content value generated by each primer

\begin{tabular}{|c|c|c|c|c|c|c|}
\hline Primer & Primer sequences 5'-3' & NTA & NPA & PPA & Size (bp) & PIC \\
\hline Myrcoml & $\begin{array}{l}\text { F: CGTGATGCACACTGAACTGA } \\
\text { R: AACCCCTTTTGCCAACATTT }\end{array}$ & 3 & 3 & 100 & $225-230$ & 0.45 \\
\hline Myrcom2 & $\begin{array}{l}\text { F: ATAGCTCTTACCCGCCATTG } \\
\text { R: GTGCATGGTCCTCGATAGGT }\end{array}$ & 9 & 9 & 100 & 213-240 & 0.88 \\
\hline Myrcom3 & $\begin{array}{l}\text { F: GGCAGCTACCAGTCATACCC } \\
\text { R: TTTGCAGCATTTCAAAGTGG }\end{array}$ & 2 & 2 & 100 & $183-187$ & 0.77 \\
\hline Myrcom4 & $\begin{array}{l}\text { F: CAACCACATCCACCCATAGA } \\
\text { R: CCACAGTCAAGAGGGAGAGC }\end{array}$ & 8 & 7 & 100 & $162-187$ & 0.52 \\
\hline Myrcom5 & $\begin{array}{l}\text { F: TGAGAGATCAGCAACCAAAAAG } \\
\text { R: CATGAATGGCAACGATGAAA }\end{array}$ & 5 & 5 & 100 & 253-269 & 0.75 \\
\hline Myrcom6 & $\begin{array}{l}\text { F: AAATGAAAAAGCTAAAAGTTAAAC } \\
\text { R: AACAGGAAGAGCAAGCCAAG }\end{array}$ & 4 & 4 & 100 & |179-181 & 0.45 \\
\hline Myrcom7 & $\begin{array}{l}\text { F: AGACATGCTCAAACTTGTATGC } \\
\text { R: AATGTATCCCAACATGTCAGA }\end{array}$ & 9 & 9 & 100 & $177-213$ & 0.87 \\
\hline Myrcom8 & $\begin{array}{l}\text { F: TGCTCGGTCATTAATTGGTGT } \\
\text { R: TCAAAACCGTCTCCATGAAA }\end{array}$ & 9 & 9 & 100 & $230-270$ & 0.99 \\
\hline Myrcom9 & $\begin{array}{l}\text { F: GAAAGTTGCACTGTTTATTTCCAA } \\
\text { R: TCTTCCTTCCAATCCTCATCA }\end{array}$ & 4 & 4 & 100 & 181-187 & 0.67 \\
\hline Myrcom10 & $\begin{array}{l}\text { F: TTAAGTGCCTTTGGCATTTGT } \\
\text { R: AGAGGACCTCGCGATAGACA }\end{array}$ & 1 & - & 100 & 166 & \\
\hline Myrcom 11 & $\begin{array}{l}\text { F: GCAAATAAAAAGCGAGTTAAATGA } \\
\text { R: CCACACTTTTAAGAATTTGTGGTC }\end{array}$ & 8 & 8 & 100 & $230-250$ & 0.97 \\
\hline Myrcom 12 & $\begin{array}{l}\text { F: CCCTCCATTTTTCCCTTCTC } \\
\text { R: AGCCGAAGCTCCAAGAAAC }\end{array}$ & 3 & 3 & 100 & $140-146$ & 0.49 \\
\hline
\end{tabular}

NTA: number of total allele, NPA: number of polymorphic allele, PPA: percentage of polymorphic allele, PIC: polymorphic information content

Table 5. List of iPBS primers and sequence, number of bands and polymorphic bands, band size range ( $\mathrm{bp}$ ) and polymorphic information content value generated by each primer

\begin{tabular}{c|c|c|c|c|c|c}
\hline Primer & Primer sequences 5'-3' & NTB & NPB & PPB & Size (bp) & PIC \\
\hline 2078 & GCGGAGTCGCCA & 8 & 5 & 62.5 & $250-1300$ & 0.63 \\
2079 & AGGTGGGCGCCA & 11 & 3 & 27.2 & $250-1500$ & 0.13 \\
2080 & CAGACGGCGCCA & 12 & 6 & 50 & $300-1500$ & 0.46 \\
2081 & GCAACGGCGCCA & 12 & 8 & 66.6 & $350-1450$ & 0.51 \\
2095 & GCTCGGATACCA & 9 & 5 & 55.5 & $245-1750$ & 0.31 \\
2221 & ACCTAGCTCACGATGCCA & 8 & 2 & 25 & $245-1500$ & 0.38 \\
2270 & ACCTGGCGTGCCA & 12 & 8 & 66.6 & $245-1750$ & 0.36 \\
2277 & GGCGATGATACCA & 12 & 10 & 83.3 & $250-1500$ & 0.31 \\
2376 & TAGATGGCACCA & 12 & 6 & 50 & $250-1650$ & 0.22 \\
2378 & GGTCCTCATCCA & 14 & 13 & 92.8 & $175-2000$ & 0.25 \\
2383 & GCATGGCCTCCA & 11 & 4 & 36.3 & $295-1500$ & 0.49 \\
2394 & GAGCCTAGGCCA & 14 & 10 & 71.4 & $250-1500$ & 0.40 \\
\hline
\end{tabular}

NTB: number of total bands, NPB: number of polymorphic bands, PPB: percentage of polymorphic band, PIC: polymorphic information content 


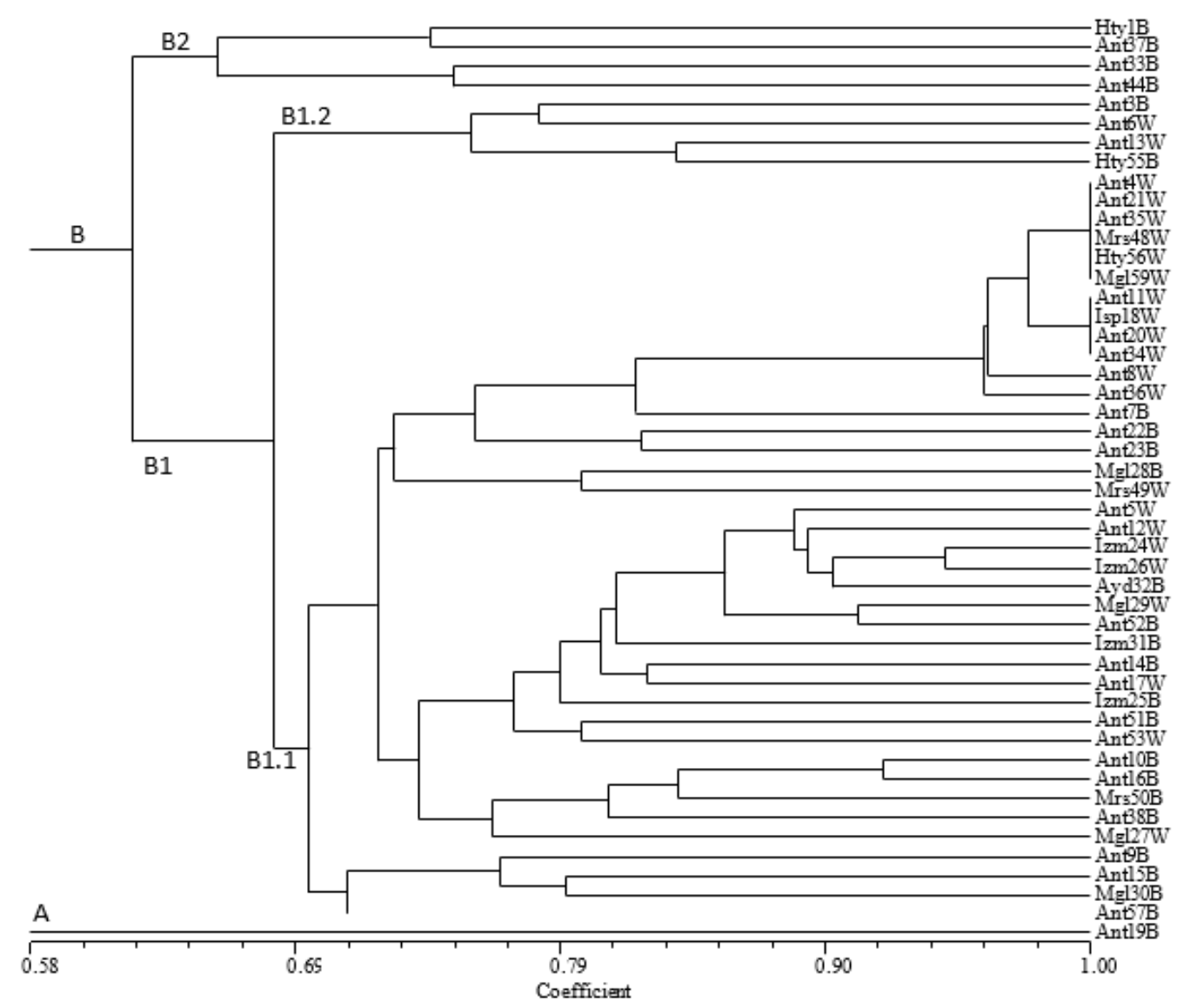

Figure 5. Dendrogram for 48 Myrtus communis accessions derived from a UPGMA cluster analysis based on 12 iPBS markers

\section{Evaluation of combined data of SSR and iPBS results with morphological findings}

Similarity coefficient ranged from 0.64 to 1.00 in the dendrogram based on UPGMA analysis performed with combined data of SSR and iPBS primers and the population divided to two main group (A and B) at the similarity value of 0.64 . Clade B comprised 8 genotypes, all with black fruit, and 7 of these genotypes were collected from Antalya province except Hty1B. Clade A divided into sub-clusters and sub-cluster A2 comprised 39 genotypes. Only one genotype (Ant 57) placed in sub-cluster A1 and appeared to be distinct from all others based on the combined SSR and iPBS based data sets (Fig. 6). The genotypes Ant4W, Mrs48W, Hty56W and Ant11W, Ant20W, Ant34W were found genetically very close (similarity index 1.00) with SSR and iPBS markers and placed together in the same clade with Ant 21W, Ant 36W and Mugl59W, Ant8W, Ant35W and Isp18W at the 0.92-0.98 similarity index value (Fig. 6). All these 12 genotypes have berries with white color and larger fruits (ranged from $0.43 \mathrm{~g}$ to $1.18 \mathrm{~g}$ with average fruit weight 0.65 ) than the other genotypes which have an average fruit weight of $0.23 \mathrm{~g}$. The average number of seeds per fruit and seed weight of these 12 genotypes 13.41 and $0.13 \mathrm{~g}$ respectively, the remaining genotypes have an average 6.77 seed per fruit and $0.07 \mathrm{~g}$ seed weight. These genotypes with white and larger berries may be semi-cultivated and selected genotypes and probably genetically very similar or identical. Our results demonstrated that the genotypes are found to be genetically indistinguishable usually consisted of berries with white color. Uzun et al. (2016) also mentioned a selected 
genotype (Hambeles) usually grown at the edges of the land with white fruit color and average $1.06 \mathrm{~g}$ fruit weight. In the current study fruit weight of the genotypes with white berries ranged from 0.06 to $1.28 \mathrm{~g}$ with average $0.48 \mathrm{~g}$ and genotypes with black berries ranged from 0.20 to 0.60 with average $0.25 \mathrm{~g}$ respectively. Messaoud et al. (2005) and Messaoud and Boussaid (2011) reported that the white fruits are smaller and showed high number of seeds per fruit than the dark blue fruit. The genetic relationship within the population of white berries and within the population with black berries were also analyzed with combined data of iPBS and SSR markers. The similarity co-efficient of genotypes with white berries and black berries ranged 0.69 to 1.00 and 0.61-0.90 respectively (Figs. $7 a$ and $8 a$ ). As seen in dendrograms the genotypes with black berries have higher genetic diversity than white ones. This result ties well with previous studies wherein similar results reported with dark blue morph population in Tunisia (Messaoud et al., 2011). In the current study the genotypes with white berries show less diversity than genotypes with black berries. At a similarity index value of 0.69 the genotypes with white berries were divided into two major clusters and first clade 6 genotypes. The second clade includes 17 genotypes and 11 of those were genetically most related and form a subgroup at the similarity index value of 0.96 (Fig. 7a). The 2D plot generated from the PCA of the combined iPBS and SSR data (Figs. $7 b$ and $8 b$ ) supported the clustering pattern of the UPGMA dendrogram. As with the scatter plot of the principal component analysis, overlapping in grouping was observed in accessions with white berries (Fig. 7b) and genotypes with black berries are dispersed (Fig. $8 b$ ).

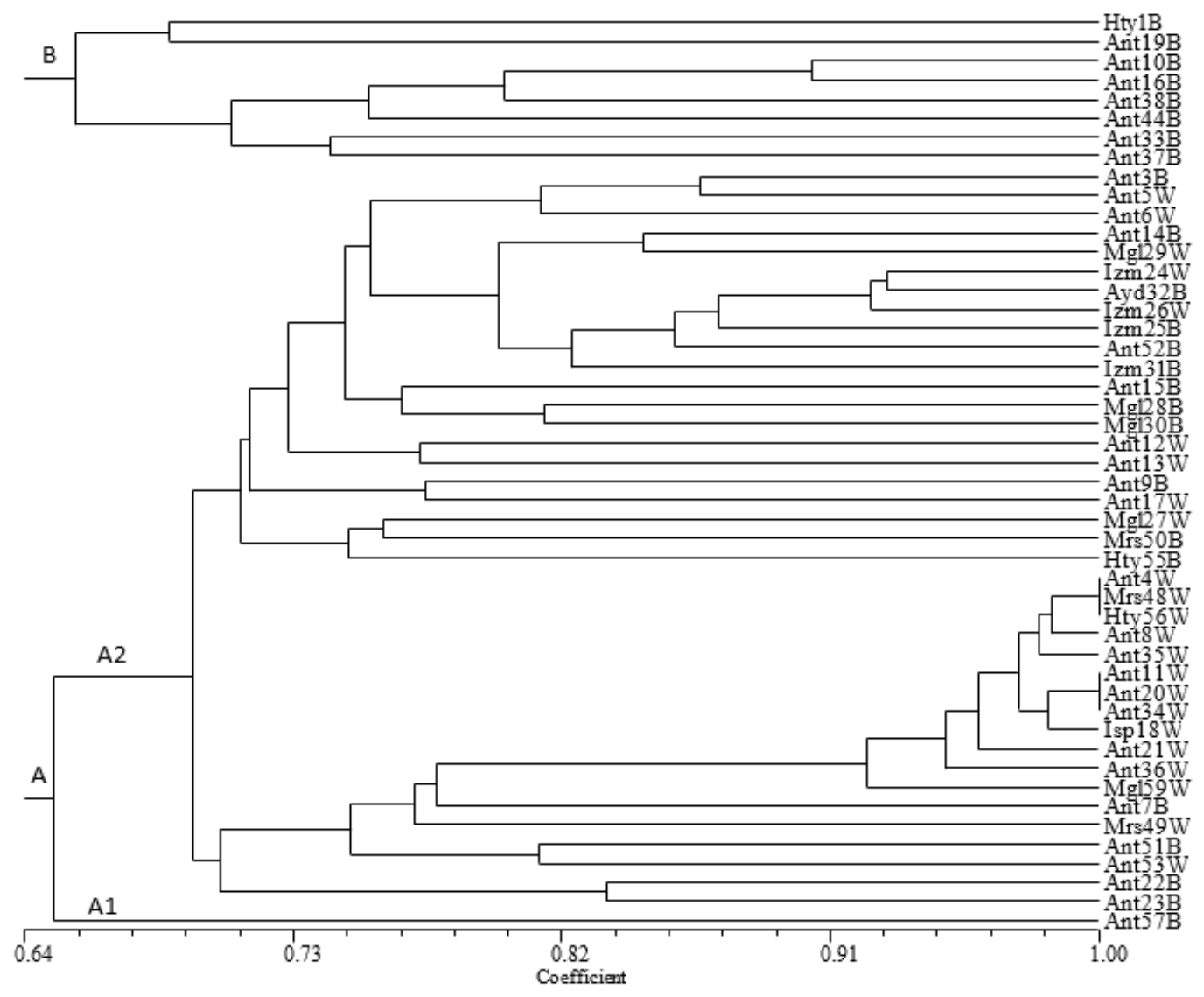

Figure 6. Dendrogram for 48 Myrtus communis accessions derived from a UPGMA cluster analysis based on combined data of iPBS-SSR markers 


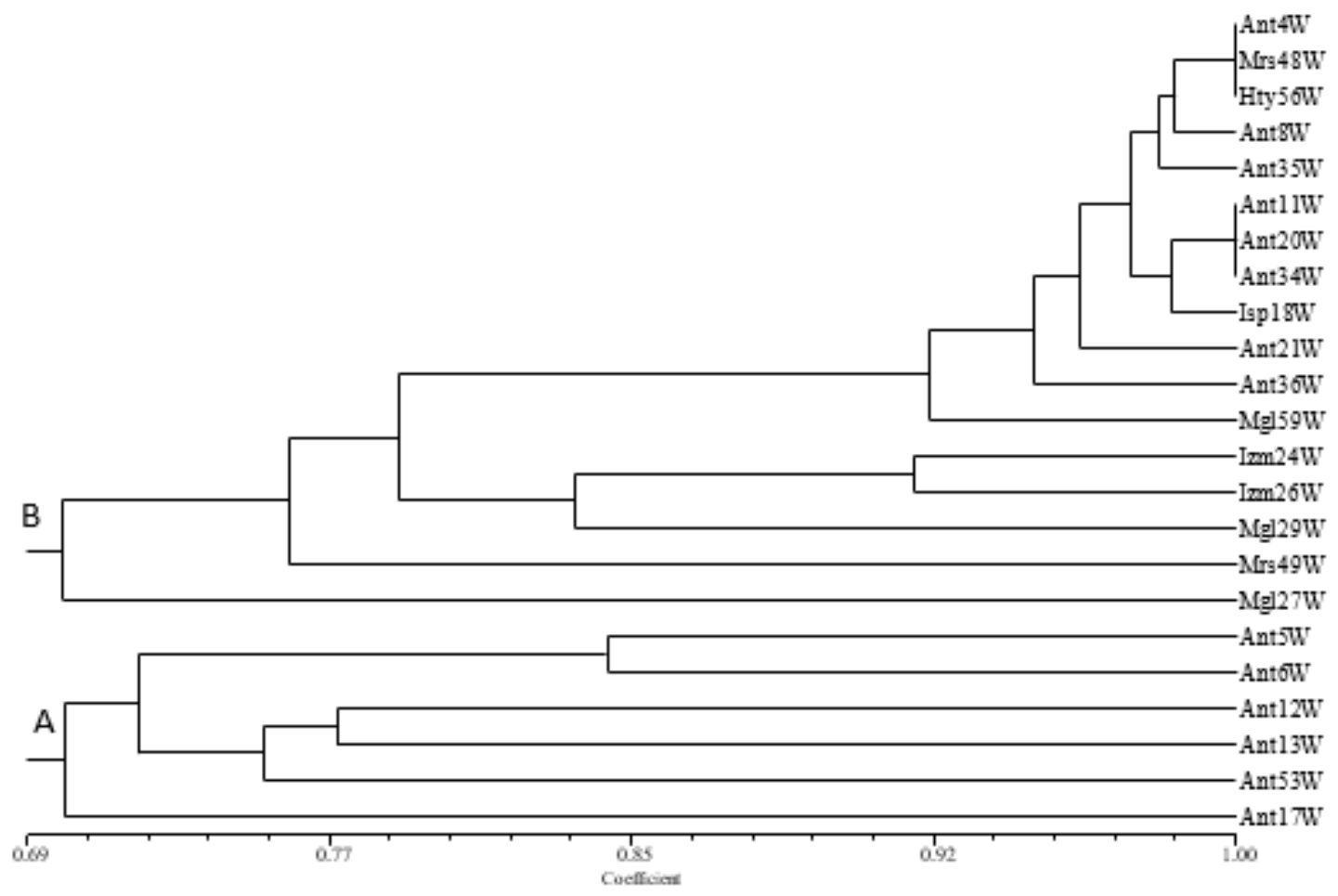

a

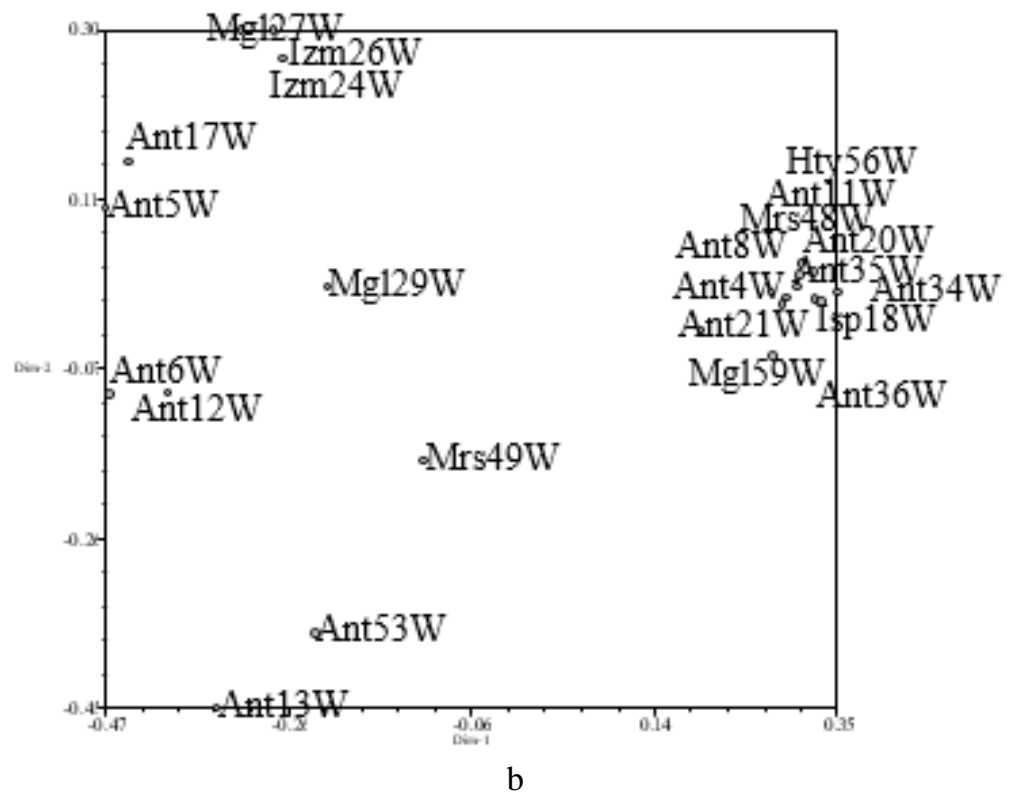

Figure 7. (a) Dendrogram for 23 Myrtus communis accessions with white fruits derived from a UPGMA cluster analysis based on combined data of iPBS-SSR markers. (b) Twodimensional plot of principal components $(P C) 1$ and 2 based on combined data of iPBS-SSR markers

Both marker techniques (iPBS and SSR) proved to be effective in discriminating the 48 genotypes. To our knowledge, iPBS primers for Myrtus communis were used for the first time in this study and according to the results obtained $1 \mathrm{PBS}$ primers can be used in phylogenetic analyzes and mapping studies of myrtle. 


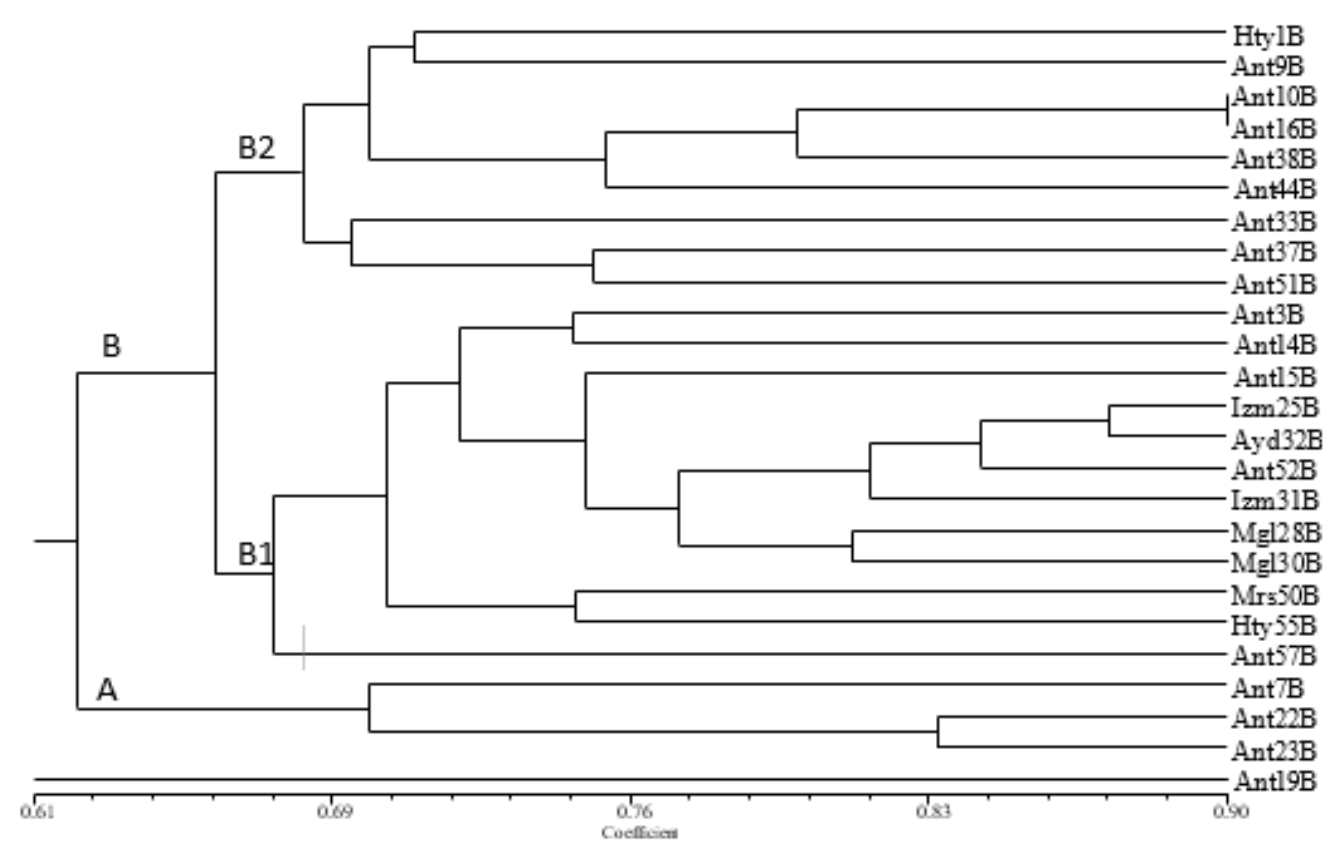

a

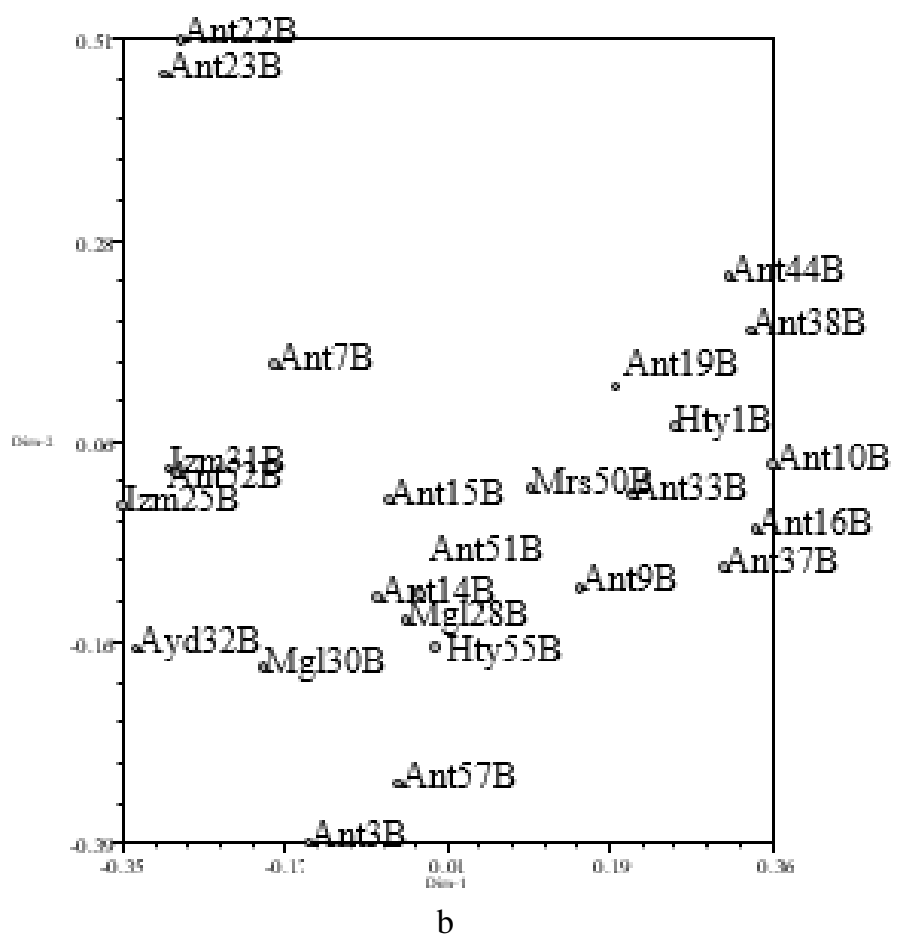

Figure 8. (a) Dendrogram for 25 Myrtus communis accessions with dark blue berries derived from a UPGMA cluster analysis based on combined data of iPBS-SSR markers. (b) Two dimensional plot of principal components $(P C) 1$ and 2 based on combined data of iPBS-SSR markers

\section{Conclusion}

Genetic diversity is fundamental for germplasm collections. Natural floras in the Mediterranean Sea Coastal of Turkey have a significant amount of myrtle (Myrtus communis) genotypes. Using genetic resources available, new cultivars can be improved 
by gathering of plants from natural flora, selection of superior species that have characteristics desired for further cultivation and breeding practices.

Characterization and evaluation of myrtle is an imperative step for germplasm conservation and utilization in the breeding programs. Moreover, characterization of available germplasm is very crucial to identify desired traits or genes. The genetic variation obtained by morphological and molecular analyzes between genotypes shows that these genotypes can be useful for future breeding and cultivation practices and can be considered as valuable genetic resources that need to be protected. These results are valuable for further reproduction and conservation programs for Myrtus communis. Additional studies to understand the genetic characteristics of the genotypes regarding the genes associated with important traits are required.

Acknowledgements. The authors would like to thank the Akdeniz University Scientific Research Projects Coordination Unit, Turkey for financial support. (Project No: FYL-2018-4201).

\section{REFERENCES}

[1] Abdurakhmonov, I. Y. (2016): Introduction to Microsatellites: Basics, Trends and Highlights. - Intech Open, London. DOI: 10.5772/66446. http://dx.doi.org/10.5772/66446.

[2] Agrimonti, C., Bianchi, R., Bianchi, A., Ballero, M., Poli, F., Marmiroli. N. (2006): Understanding biological conservation strategies: a molecular-genetic approach to the case of myrtle (Myrtuscommunis L.) in two Italian regions: Sardinia and Calabria. Conservation Genetics 8: 385-396.

[3] Albaladejo, R. G., Carrillo, L. F., Aparicio, A., Fernández-Manjarrés, J. F., González-Varo, J. P. (2009): Population genetic structure in Myrtus communis L. - in a chronically fragmented landscape in the Mediterranean: can gene flow counteract habitat perturbation? - Plant Biology 11(3): 442-453.

[4] Albaladejo, R. G., Sebastiani, F., Gonzalez-Martinez, S. C., Gonzalez-Varo, J., Vendramin, G. G., Aparicio, A. (2010): Isolation of microsatellite markers for the common Mediterranean shrub Myrtus communis (Myrtaceae). - Am J Bot 97(5): e23-5. DOI: 10.3732/ajb.1000060.

[5] Andeden, E. E., Baloch, F. S., Derya, M., Kilian, B., Özkan, H. (2013): iPBSRetrotransposons-based genetic diversity and relationship among wild annual Cicer species. - J. Plant Biochem. Biotechnol. 22: 453-466 https://doi.org/10.1007/s13562-0120175-5.

[6] Baloch, F. S., Alsaleh, A., de Miera, L. E. S., Hatipoglu, R., Çiftçi, V., Karakoy, T., Yildiz, M., Ozkan, H. (2015): DNA based iPBS-retrotransposon markers for investigating the population structure of pea (Pisum sativum) germplasm from Turkey. - Biochemical Systematics and Ecology 61: 244-252.

[7] Baránek, M., Meszáros, M., Sochorová, J. Čechová, J., Raddová, J. (2012): Utility of retrotransposon-derived marker systems for differentiation of presumed clones of the apricot cultivar Velkopavlovická. - Sci Hortic-Amsterdam 143: 1-6.

[8] Borna, F., Luo, S., Ahmad, N. M., Nazeri, V., Shokrpour, M., Trethowan, R. (2016): Genetic diversity in populations of the medicinal plant Leonurus cadiaca L. Revealed by inter-primer binding site (iPBS) markers. - Genetic Resources and Crop Evolution 64: 479-492.

[9] Bruna, S., Mercuri, A., Cervelli, C., Braglia, L., De Benedetti, L., Schiva. T. (2005): Genetic characterization of Myrtus communis L. wild genotypes using AFLP markers. Acta Horticulturae 683: 431-436. 
[10] Bruna, S., Portis, E., Cervelli, C., De Benetti, L., Schiva, T., Mercuri, A. (2007): AFLPbased genetic relationships in the Mediterranean myrtle (Myrtus communis L.). - Scientia Horticulturae 113: 370-375.

[11] Ciccarelli, D., Garbari, F. and Pagni, A. M. (2008): The flower of Myrtus communis (Myrtaceae): Secretory structures, unicellular papillae, and their ecological role. - Flora 203: 85-93.

[12] Corona, L., Mele, C., Chessa, I., Mulas, M. (2017): Analysis of Sardinian myrtle (Myrtus communis L.) germplasm selections by SSR markers. - Acta Hortic. 1172: 165-170. DOI: 10.17660/ActaHortic.2017.1172.32.

[13] Doyle, J. J., Doyle, J. L. (1990): Isolation of plant DNA from fresh tissue. - Focus 12: 13-15.

[14] D’Urso, G., Sarais, G., Lai, C., Pizza, C., Montoro, P. (2017): LC-MS based metabolomics study of different parts of myrtle berry from Sardinia (Italy). - J Berry Res. 7(3): 217-29.

[15] Ghafouri, F., Rahimmalek, M. (2018): Genetic structure and variation in different Iranian myrtle (Myrtus communis L.) populations based on morphological, phytochemical and molecular markers. - Industrial Crops \& Products 123: 489-499.

[16] Kalendar, R., Schulman, A. H. (2014): Transposon-based tagging: IRAP, REMAP, and iPBS. - Methods Mol. Biol 1115: 233-255.

[17] Kalendar, R., Antonlus, K., Smykal, P., Schulman, A. (2010): iPBS: a universal method for DNA fingerprinting and retrotransposon isolation. - Theor Appl Genet 1211: 14191430.

[18] Karık, Ü., Nadeem, M. A., Habyarimana, E., Ercisli, S., Yildiz, M., Y1lmaz, A., Yang, S. H., Chung, G., Baloch, F. S. (2019): Exploring the genetic diversity and population structure of Turkish laurel germplasm by the iPBS-retrotransposon marker system. Agronomy 9(10): 647. https://doi.org/10.3390/agronomy9100647.

[19] Kuras, A., Antonius, K., Kalendar, R., Kruczynska, D., Korbin, M. (2013): Application of five DNA marker techniques to distinguish between five apple (Malus $\times$ domestica Borkh.) cultivars and their sports. - J Hortic Sci Biotechnol 88(6): 790-794. https://doi. org/10.1080/14620 316.2013.11513040.

[20] Medda, S., Mulas, M. (2021): Fruit quality characters of myrtle (Myrtus communis 1.) selections: review of a domestication process. - Sustainability 13(16): 8785. https://doi.org/10.3390/su13168785.

[21] Medda, S., Fadda, A., Dessena, L., Mulas, M. (2021): Quantification of total phenols, tannins, anthocyanins content in Myrtus communis L. and antioxidant activity evaluation in function of plant development stages and altitude of origin site. - Agronomy 11(6): 119.

[22] Mehmood, A., Luo, S., Ahmad, N. M., Dong, C., Mahmood, T., Sajjad, Y., Jaskani, M. J., Sharp. P. (2015): Molecular variability and phylogenetic relationships of guava (Psidium guajava L.) cultivars using inter-primer binding site (iPBS) and microsatellite (SSR) markers. - Genet. Resour. Crop. Ev. 63(8): 1345-1361. https://doi. org/10.1007/s1072 2-015-0322-7.

[23] Mele, C., Corona, L., Melito, S., Raggi, L., Mulas, M. (2019): The genetic diversity of selections and wild populations of myrtle revealed by molecular geographic contexts. Industrial Crops \& Products 132: 168-176.

[24] Melito, S., Chessa, I., Erre, P., Podani, J., Malus. M. (2013): The genetic diversity of Sardinian myrtle (Myrtus communis L.) populations. - Electronic Journal of Biotechnology 16(6).

[25] Melito, S., Fadda, A., Rapposelli, E., Mulas, M. (2014): Genetic diversity and population structure of Sardinian myrtle (Mytrus communis L.) selections as obtained by AFLP markers. - Hort Science 49: 531-537.

[26] Melito, S., La Bella, S., Martinelli, F., Cammalleri, I., Tuttolomondo, T., Leto, C., Fadda, A., Molinu, M. G., Mulas. M. (2016): Morphological, chemical, and genetic diversity of 
wild myrtle (Myrtus communis L.) populations in Sicily. - Turkish Journal of Agriculture and Forestry 40(2): 249-261.

[27] Melito, S., Dessena, L., Sale, L., Mulas, M. (2017): Genetic diversity and population structure of wild Sardinian myrtle (Myrtus communis L.) genotypes from different microclimatic areas. - Australian Journal of Crop Science 11(11): 1488-1496.

[28] Messaoud, C., Boussaid. M. (2011): Myrtus communis berry color morphs: a comparative analysis of essential oils, fatty acids, phenolic compounds and antioxidant activities. Chemistry \& Biodiversity 8(2): 300-310.

[29] Messaoud, C., Zaouali, Y., Ben Salah, A., Koudja, M. L., Baussaid, M. (2005): Myrtus communis in Tunisia: variability of the essential oil composition in natural populations. Flavourand Fragrance Journal 20: 577-582.

[30] Messaoud, C., Afıf, M., Boulila, A., Rejeb, M., Boussa1d. M. (2007): Genetic variation of Tunisian Myrtus communis L. (Myrtaceae) populations assessed by isozymes and RAPDs. - Annals of Forest Science 64: 845-853.

[31] Messaoud, C., Bejaoui, A., Boussaid. M. (2011): Fruitcolor, cheminal and genetic diversity and structure of Myrtus communis L. var. Italica Mill. morphpopulations. Biochemical Systematics and Ecology 39: 570-580.

[32] Milovanov, A., Zvyagin, A., Daniyarov, A., Kalendar, R., Troshin, L. (2019): Genetic analysis of the grapevine genotypes of the Russian Vitis ampelographic collection using iPBS markers. - Genetica 147: 91-101.

[33] Mulas, M., Cani, M. R. (1999): Germplasm evaluation of spontaneous myrtle (Myrtus communis) for cultivar selection and crop development. - Journal of Herbs, Spices and Medicinal Plants 6: 3: 31-49.

[34] Mulas, M., Cani, M. R., Brigaglia. N. (1998): Characters useful to cultivation in spontaneous populations of Myrtus communis L. - Acta Horticulturae 457: 271-278.

[35] Nora, S., Albaladejo, R. G., Aparicio, A. (2014): Genetic variation and structure in the Mediterranean shrubs Myrtus communis and Pistacia lentiscus indifferent landscape contexts. -PlantBiology 17: 311-319.

[36] Özek, T., Demirci, B., Baser, K. H. C. (2000): Chemical composition of Turkish myrtle oil. - J Essent Oil Res. 12: 541-544.

[37] Özkan, A. M. G. Güray, Ç. G. (2009): A Mediterranean: Myrtus Communis L. (Myrtle). In: Morel, J. P. Mercuri, A. M. (eds.) Plants and Culture: Seed of the Cultural Heritage of Europe. Edipuglia, Bari, pp.158-168.

[38] Park, Y. J., Lee, J. K., Kim, N. S. (2009): Simple sequence repeat polymorphisms (SSRPs) for evaluation of molecular diversity and germplasm classification of minor crops. - Molecules 14: 4546-4569. DOI: 10.3390/molecules14114546.

[39] Rohlf, F. J. (1993): NTSYS-pc. Version 1.X0. - Exeter Software, Setauket, NY.

[40] Roldan-Ruiz, I., Dendauw, J., Van Bockstaele, E., Depicker, A., De Loose. M. (2000): AFLP markers reveal high polymorphic rates in ryegrasses (Lolium spp.). - Mol Breed. 6: 125-134. DOI: 10.1023/A:1009680614564.

[41] Schuelke, M. (2000): An economic method for the fluorescent labeling of PCR fragments. - Nature Biotechnology 18: 233 - 234.

[42] Sepici, A., Gurbuz, I., Cevik, C., Yesilada. E. (2004): Hypoglycaemic effects of myrtle oil in normal and alloxan-diabetic rabbits. - J Ethnopharmacol 93(2-3): 311-318.

[43] Serçe, S., Ekbiç, E., Suda, J., Gündüz, K., Kiyga. Y. (2010): Karyological features of wild and cultivated forms of myrtle. - Genetic and Molecular Research 9(1): 429-433.

[44] Simsek, O., Donmez, D., Sarıdas, M. A., Paydas-Karg1, S., Aka-Kacar, Y. (2019): Genetic relationship and polymorphism of Turkish myrtles (Myrtus communis L.) as revealed by inter simple sequence repeat (ISSR). - Applied Ecology and Environmental Research 18(1): 1141-1149.

[45] Traveset, A., Núr1a, R., Mas, R. E. (2001): Ecology of fruit-colour polymorphism in Myrtus communis and differential effects of birds and mammals on seed germination and seedling growth. - Journal of Ecology 89: 749-76. 
[46] Usai, M., Marchetti, M., Culeddu, N., Mulas, M. (2020): Chemotaxonomic evaluation by volatolomics analysis of fifty-two genotypes of Myrtus communis L. - Plants. 9(10): 120.

[47] Uzun, H. İ., Aksoy, U., Gözlekçi, Ş., Bayır Yeğin, A., Selçuk, N. (2016): Studies on the yield and quality characteristics of myrtle (Myrtus communis L.) grown in two different ecologies. - Derim 33(2): 159-174 (in Turkish).

[48] Yıldırım, H., Karg1, S., Karabıyık. Ş. (2013): Research on naturally grown myrtle (Myrtus communis L.) plants at Adana and Mersin ecological conditions. - Alatatarım 12(1): 1-9 (in Turkish). 